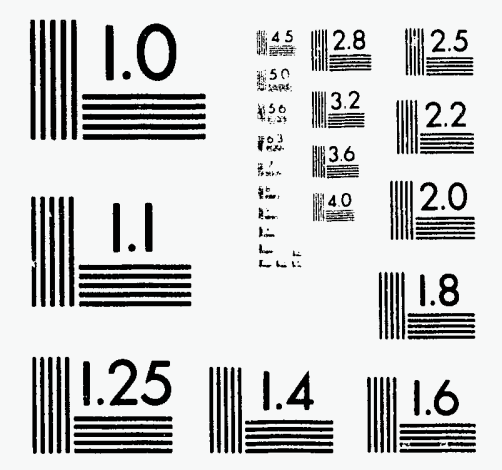



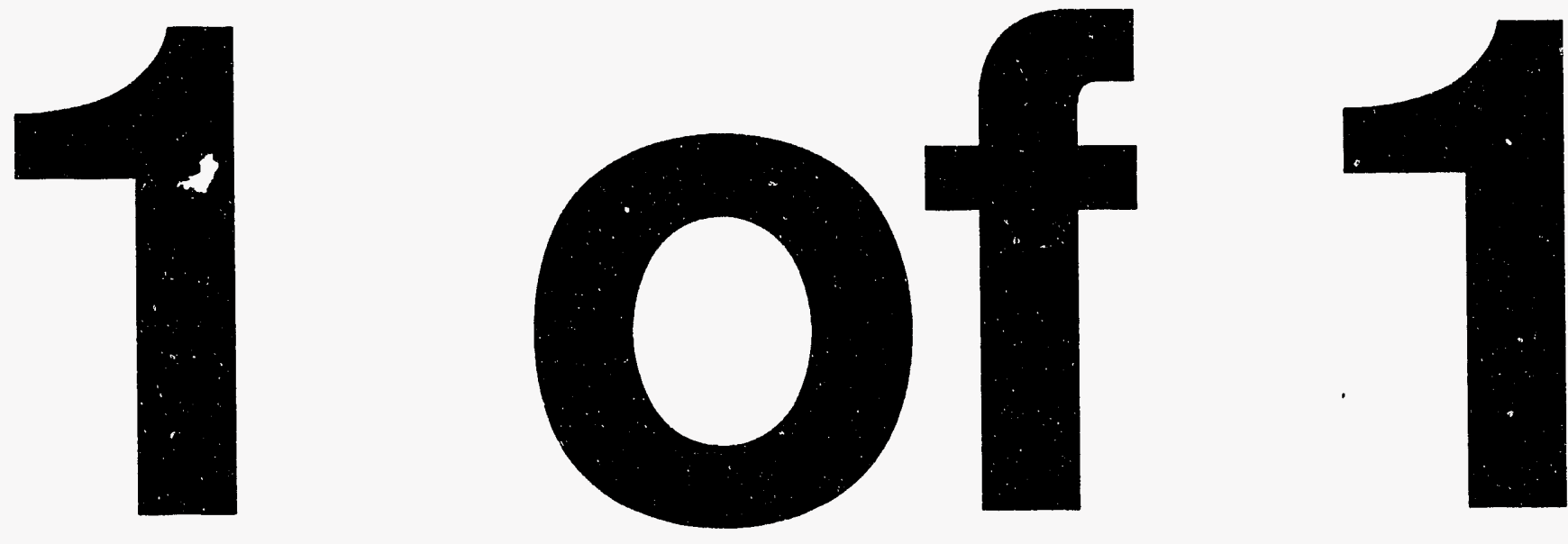


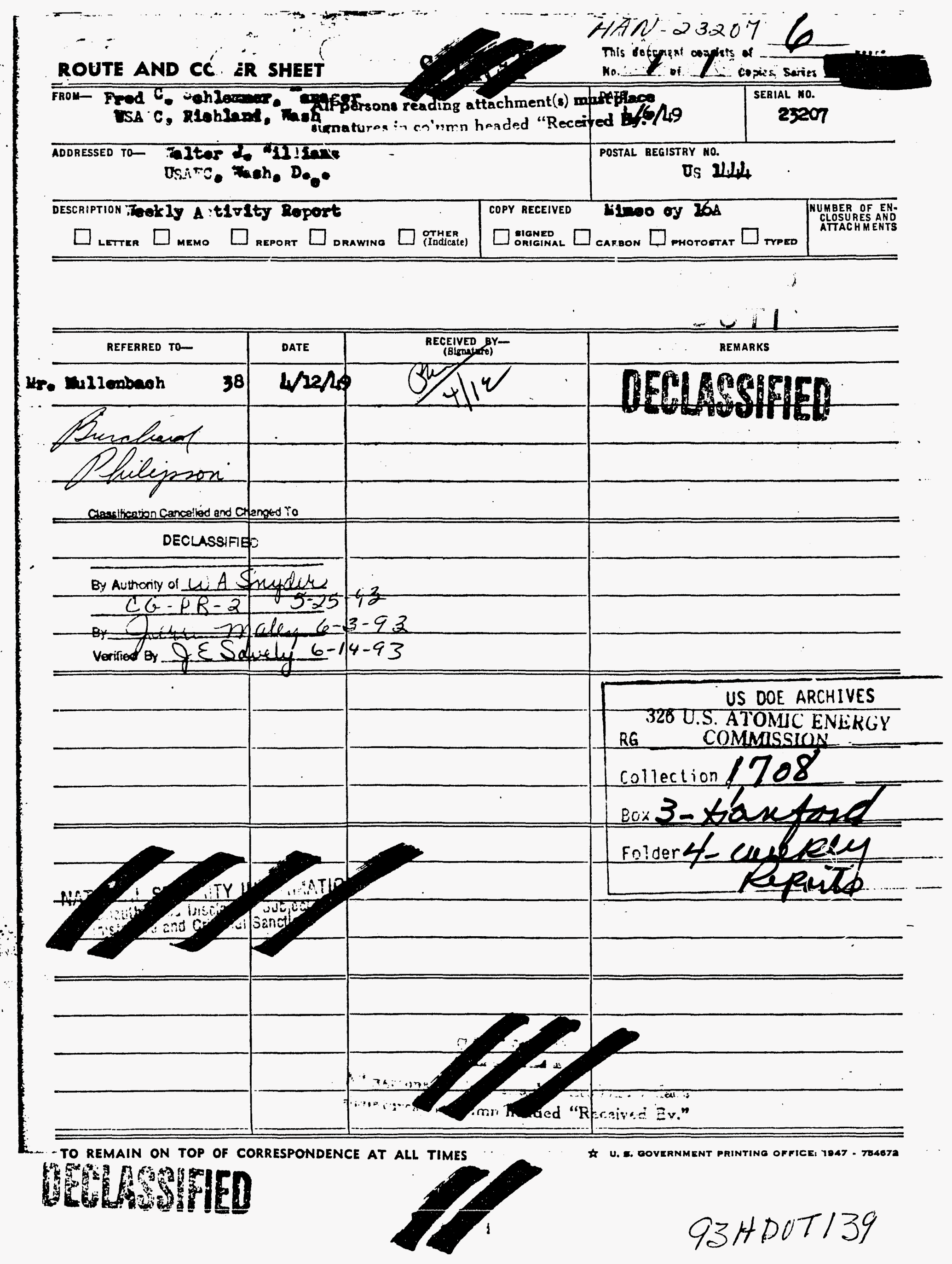


TO: Talter J. Williams, USAEC, Vashington, D. C.

FROM: Fred C. Schlemer, Manager, Hanford Operations

Office, Richland, Nashington

EVENTS CF IIIPORTANCE FOR WEER EINDINO APRII 6, 1949

SIMBOL: ICH:RWR

Enclosed is subject report for week ending April 6, 1949.

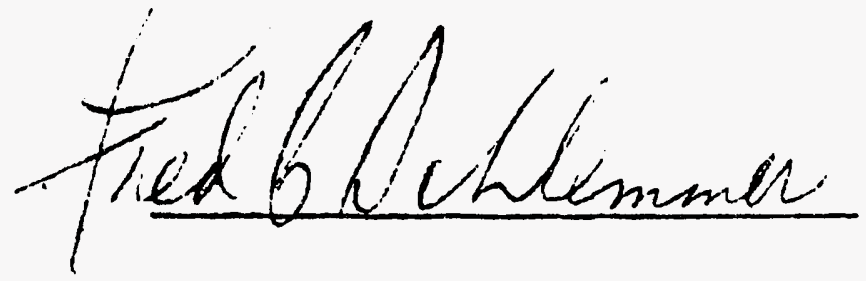

Encli Copies thru it

\section{DOE. ARCHIVES}

When separated from enclosures handle

this document as Unclassified

\section{DISCLAIMER}

This report was prepared as an account of work sponsored by an agency of the United States Government. Neither the United States Government nor any agency thereof, nor any of their employees, makes any warranty, express or implied, or assumes any legal liability or responsi-

AIR MAIL bility for the accuracy, completeness, or usefulness of any information, apparatus, product, or process disclosed, or represents that its use would not infringe privately owned rights. Reference herein to any specific commercial product, process, or service by trade name, trademark, manufacturer, or otherwise does not necessarily constitute or imply its endorsement, recommendation, or favoring by the United States Government or any agency thereof. The views and opinions of authors expressed herein do not necessariily state or reñeci thuse of the United States Government or any agency thereof. 


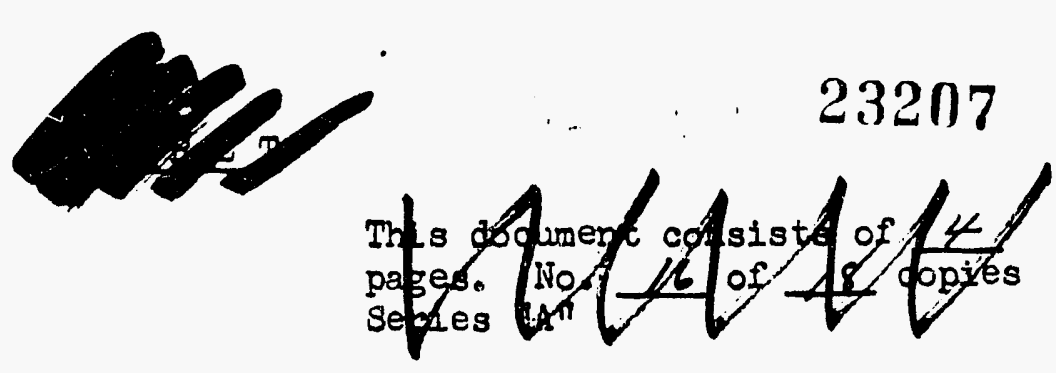

EVEITS OF THPORTALNE FOR TEEE EIDING APRII 6, 1949

Hanford Operations Office

Richland, Fashington

\section{I - ADMINISTRATION:}

No significant events to report.

II - OPERATIONS:

Metal Waste Program:

Two one-hundred galion samples of two-year old metal waste solution were taken from the 103-T tank on March 31, and shipped from Hanford on April 6, as scheduled.

Stuck Slug:

The slugs in the stuck tube at $F$ pile, reported last week, have veen examined. One slug was badly warped; several slugs were moderately blistered.

Rala:

Representatives of General Electric and Hanford Operations Office will attend a meeting at Los Alamos on April 14 to discuss technical and policy questions concerning the Rala programs at the various sites.

A 76-slug shipment is scheduled to leave Richland for Oak Ridge on April 13, inaugurating a three-week schedule to continue until the end of June.

\section{P-10:}

A shipment of $30 \mathrm{LI}-\mathrm{Al}$ slugs was made to Chicago on April 6. The pieces had been exposed for 105.4 effective days, with an average exposure of 200.8 IUTD per adjacent ton.

Redox:

DOE ARCHIVES

A second successful hexone ignition test was conducted on April 6 using a 55 gallon drum containing pure dry hexone. The drum was under 20 pounds pressure with the iiquid temperature at 44 degrees centigrade.

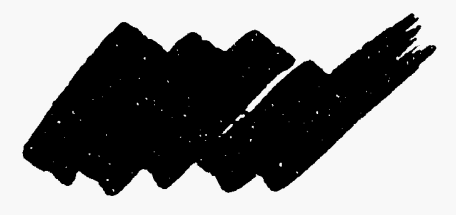


III - CUNISIRUCTION:

Process Areas:

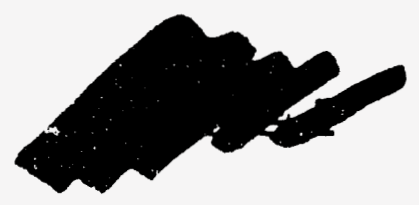

\section{0 (Pile) Areas:}

100-H - The seventh tier of "B" blocks is being installed on both the inlet and outlet faces of the pile. Other worle in progress on the pile includes checking the base cast iron and instaling side cast iron, welding flanges and amega seal, and preparatory work. incident to gun barrel installation. The 105-H Building is estimated to be $59 \%$ complete.

100-DR - Four items remain to be completed on the 105-DR check list.

Pile Area Qeneral - Giffuls and Vallet have submitted recommendations for the repair of the 107-DR and 107-H retention basins; sixteen bottom slabs heaved by ice under the slabs are to be replaced an? expansion joints repaired. The repair to 107-DR is estimated to cost $\$ 54,000$, and repair to $107-\mathrm{H}$ is estimated at $\$ 18,000$. The number of test wells at the 107-DR retention basin has been reduced from 13 to 8; 4 have been completed to 35 feet. Electricians, except maintenance personnel, are still on strike on all Atkinson \& Jones projects. Installation of segmental discharge equipment in the pile buildings has been postponed indefinitely.

P-10 - P-10A - Project P-10 has been closed out as 100\% complete. Some minor work remaining will be charged to $P-10-A$, which is now $8 \%$ complete.

\section{0 (Separation) Areas:}

\section{DOE ARCHIVES}

234-5 - Pipe on duct level is complete and being tested. The second floor piping sholidd be ready for test April 7, except that a lack of expansion vilves and heat exchangers is delaying completion of the refrigeration units. Fone of the American District Telegraph Company protective control locks have been received. Jurisdictional disputes have prevented the installation of the Johnson Service Panel, and the electricians strike has prevented balancing of the ventilat ing system. The entire project is considered $95.4 \%$ complete, and the 2345 Building is considered $97.9 \%$ complete.

Waste Storage - The 24I-BY waste storage project is now $55 \%$ complete. Steel tank erection is complete except for repair welding of the last two tanks. Ten tanks have been set down, and walls on six tanks have been poured.

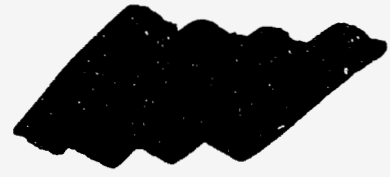


Richland Village:

Housing - Exterior painting of 301 "ranch" type houses, some utility u $\therefore$ anc. 5 installation of 303 elothes poles remain to be completec : joject. The invitation to bid on the telephone system in the are: is being revised to include splicing. General mlectric had origina:-' planned to do this jork.

Schools - All undelivered items wich have been delaying completion of the schools should be received ththin three reeks. This should allow construction to be closed out on the schools by kay $5,1949$.

\section{Hiscellaneous Construction:}

Commerciol Firms - Construction by private firms of t:o store buildings In the centril commercinl zone is $50 \%$ complete. No other building has been started.

Water Supply - Silt has been removed from the sitkinson \& Jones mell plts and rater from the irrigation line tumed into the charging basin; rapid percolation is indicated. Irrigntion rater mas turned into the iverport, $\mathbb{R} \in \mathrm{rn}$ \& Kibbe Company rell pit, the vacuum pump instillet, thle river purp primec and struted, and a satisfactory flor of rater into the basin obtained. A report fron ilford, Burdick \& Horsen on the 1949 inter supply plans is scheduled for April 10.

Southorn Railroad Connection - Approximately 90\% of the Southern Railroad connection plans have been submitted to the Comaission for approval.

Richland dutonatic Telephone System - Sixteen additional relay cabinets have arrived and are in place. This project is not 77\% complete,

$115 \mathrm{IV}$ Irnsalssion Line and Substations - Gonernl Electric portion of Substation 1752; on Thayer Drive is 85\% conplete; three prinary feeces: are nor energized and five renain. General Electric construction on Substation $1152 B$ on Stevens Drive is $100 \%$ complete isth all seven feeders energized. Sone deletions from the scott-Buttner contract are being considered and a ner lump sun contract arrarded for the zork because of interference ith the existing $66 \mathrm{BV}$ line which must be kept in servicc.

\section{Personnel:}

\section{DOE ARCHIVES}

There are approxinatcly 746 architect-engineer (Iess Tumbull) and 9,610 construction exployees on the pay roll. Construction camp population is 8,896 .

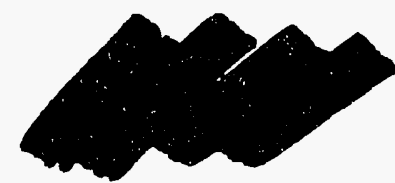


I.S. Ruben C. Carlson, representing the Du Pont and General Electiri: Companies, and iir. Berryman Green, of the Department of Justice, Mashington, D. O., visited the project as well as Messrs. Wax Kaminoff and Jess Rosenberg, of the Attorney Generals Office, State of Washington. The subject of the visit was the litigation between the afore mentioned companies and the State of Washington in regard to Business and Occupation Taxes.

Mr. R. W. Fenwick, reporter for the Denver Post, Denver, Colorado, visited the area to investigate charges of waste on the project.

Col. William Whipple and Lir. R. L. Drake, of the Corps of Engirieers, Talla $\mathrm{Talla}$, Mashington, visited the project in regard to flood protection.

liessrs. Qeorge S. Shegog and Donald Ellsworth, from the firm of Lybrand, Ross Bros., and :iontgomery, were visitors in connection with the plant appraisal program.

Captain G. E. Horn, of the Second Infantry Division, Fort Levis, Viashington, visited the project to observo the proposed Bailey bridge installation over the Yakima River. The possibility of using engineer troops to install the bridge as part of a training problem was discussed.

Iir. J. P. Jolliffee, of the Bonneville Power Administration, visited in connection with the operation of synchronous motors. He also discussed the operation of the Grand Coulee Dam for flood control purposes.

\section{$V$ - SCIENECTADY:}

\section{DOE ARCHIVES}

Weekly construction progress and activity reports from the schenec tady Office are to be forvarded directly to the Washington Office commencing with the report for the pertod ending April 6, 1949.

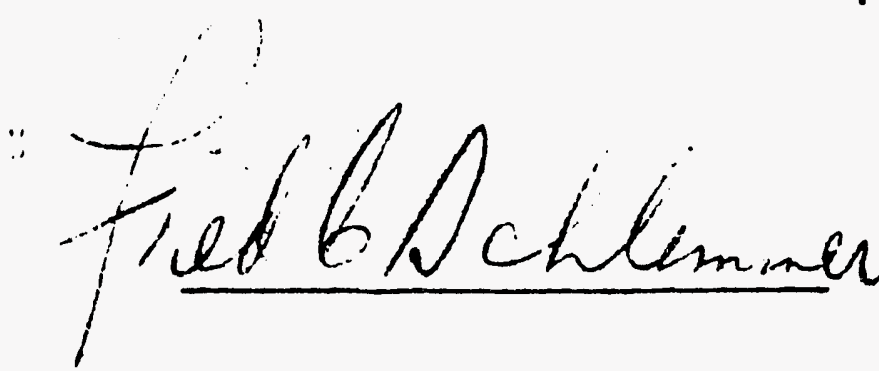



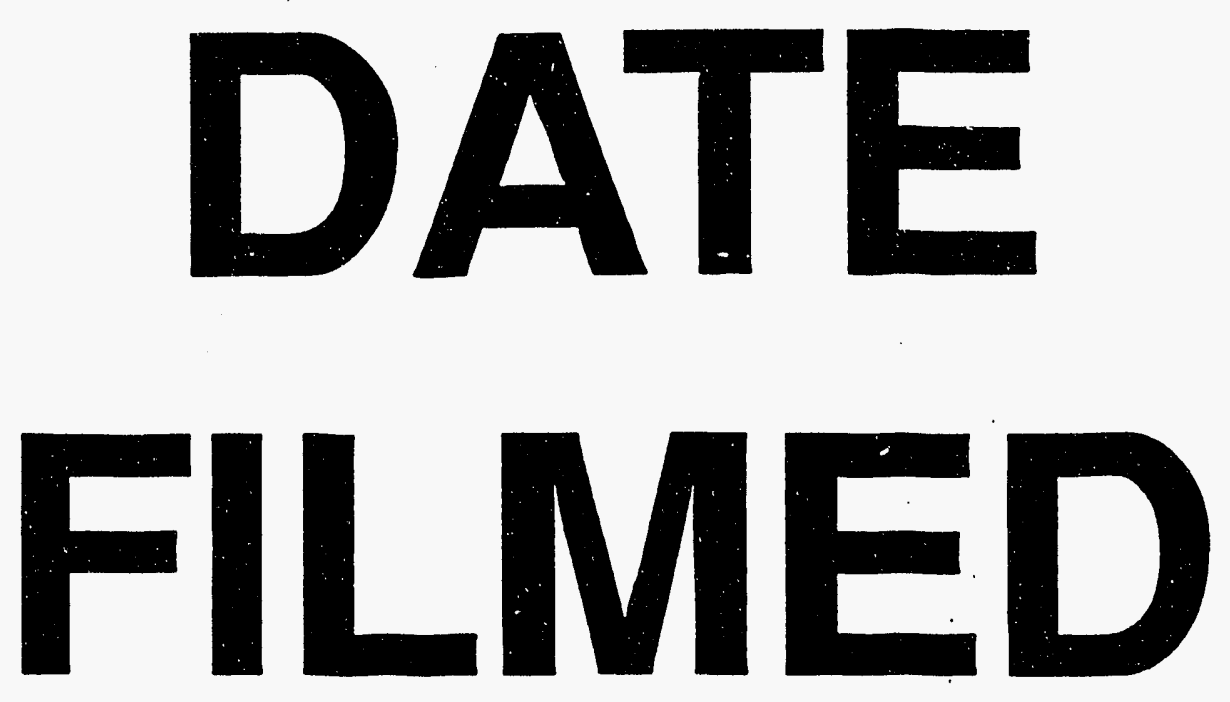

$10 / 13 / 93$
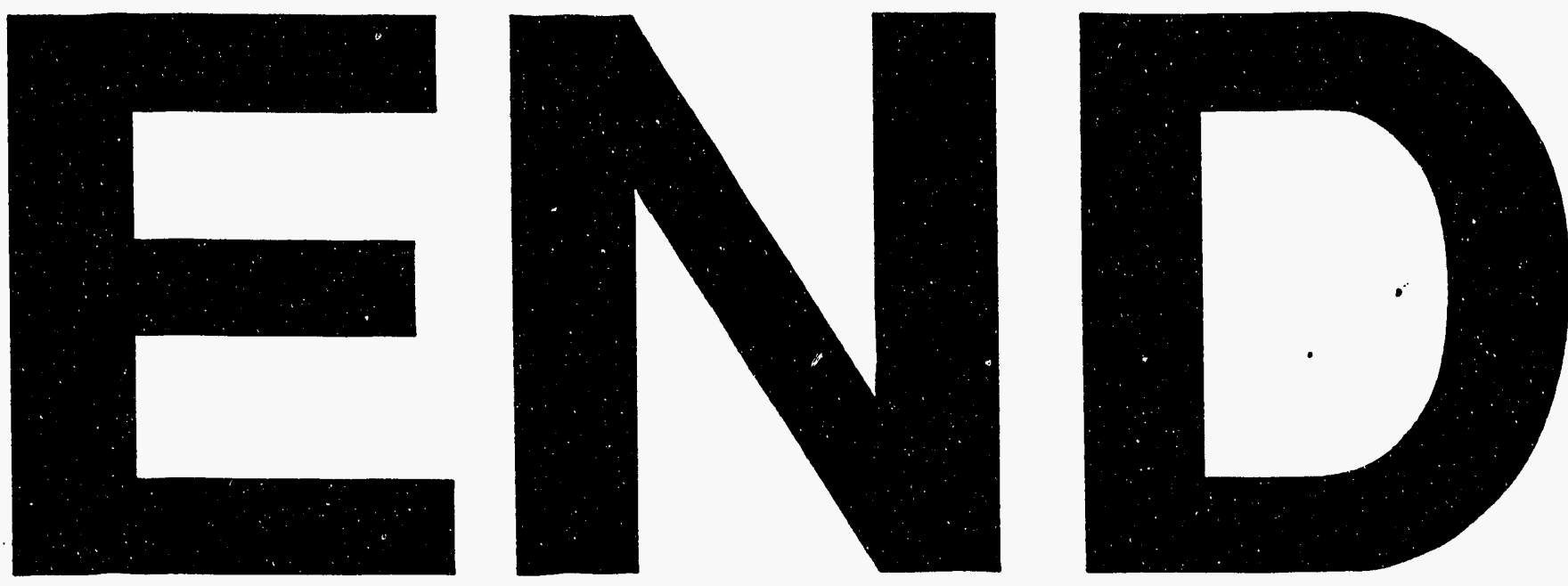
